\title{
DESIGN INNOVATIONS TOWARDS ENHANCING THE QUALITY OF LIVING IN MULTI-STOREY COMPOUND HOUSING FOR LOW-INCOME HOUSEHOLDS IN KUMASI, GHANA
}

\author{
S. O. Afram ${ }^{1}$ and S. E. Owusu ${ }^{2}$ \\ ${ }^{1}$ Department of Architecture, Faculty of Architecture and Building Technology \\ ${ }^{2}$ Institute of Human Settlements Research (IHSR), \\ College of Architecture and Planning, KNUST, Kumasi
}

\begin{abstract}
A large number of low-income households in Kumasi, in the Ashanti Region, live in compound houses. The earlier compound houses built in mud are mostly single-storey but this has gradually metamorphosed, over the years, into multi-storey compound houses within the urban areas. This has been attributed mainly to the high land values and efforts by landlords to maximize the use of land, thereby absorbing the large number of urban poor who lack accommodation. The incidence of a large number of rooms with this kind of design enable cost of renting a room to be cheaper and thus accessible to the poor. This paper seeks to present the merits and demerits of the compound house through studies conducted by the Department of Architecture, from 1985 to 2005, as well as employing an "archito-centric" approach to solving some of the problems, especially the preparation of fufu on upper floors of the building, washing and drying of laundry, refuse disposal, cooking, circulation and storage.
\end{abstract}

Keywords: Multi-storey compound housing, low-income housing, design innovations, Kumasi.

\section{INTRODUCTION}

The compound house is one of the most versatile housing designs that most low-income households presently enjoy in Ghana, particularly in Kumasi, the capital city of the Ashanti Region. Kumasi, with a population of 1,170, 270 in year 2000, is the second largest city in Ghana (Statistical Service, 2002). The compound house has many advantages, which if exploited, may be adopted to solve the perennial accommodation problems of people within the low -income bracket in urban areas in the country.

Most of the compound houses are single storey but with rising land values within the urban environment, house owners, being economically prudent, started building vertically. However, with these multi-storey developments, activities which could normally be carried out on the ground within the courtyard of a single storey compound house could not be done effectively on the upper floors. Some of these activities are children playing, washing and drying of clothes, cooking and the preparation of fufu, the stable food of the Ashantis.

This paper seeks to pursue an "archito-centric" approach to show how future designs of these multi-storey structures could be sensitively handled to accommodate four important aspects of the lifestyle of the lowincome households on the upper floors of multi-storey compound houses. These are:

Fufu preparation (especially pounding);

Washing and drying of clothes;

Refuse disposal; and

Utility space (for cooking, storage and relaxing).

Since the compound housing principle is more towards communal living and the sharing of facilities, these would be harnessed to achieve these four activities mentioned above, thereby strengthening the cultural and family ties which, as it were, are trademarks of the typical Ghanaian and more especially the residents of the Ashanti Region.

\section{SOURCES OF DATA}

The basis for this paper are the results of research carried since 1985 with students of the Department of Architecture of the Kwame Nkrumah University of Science and Technology, (KNUST) Kumasi, in suburbs of Kumasi. The studies are (Fig. 1a):

Ayigya residential district Study (1985) 
Asawasi Housing Survey (1996)

Aboabo Residential Building Study (2001)

Bantama Urban Study (2005)

Adum Urban Study (2004)

Bompata Precinct Study (2005)

In these studies, samples ranging from 40 to 70 percent of the houses were taken. The studies involve socio-economic background of the suburbs, assessment of the properties, especially the houses in terms of architectural designs and space use.

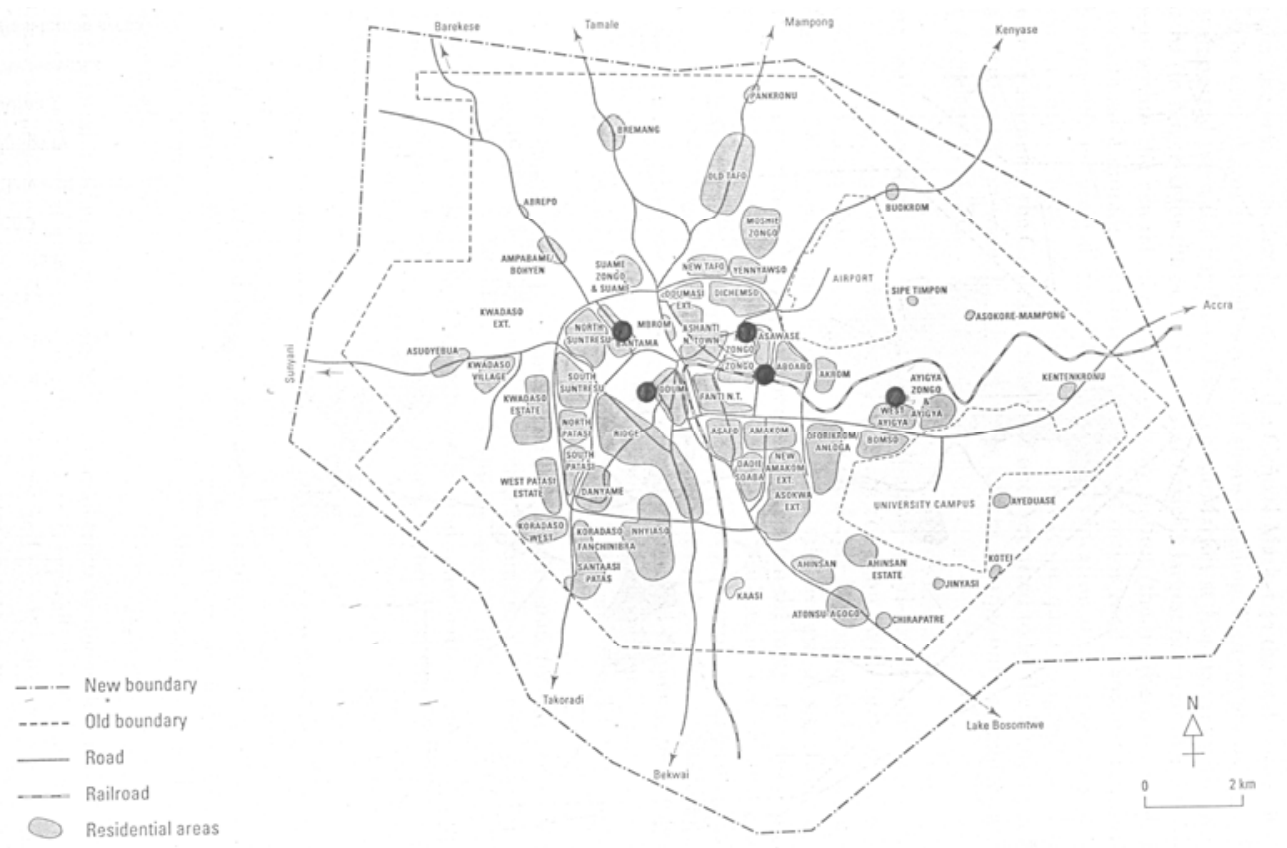

Fig. 1a: Residential Area of Kumasi Showing Study Areas

Source: Tipple, 1987

\section{HOUSING IN KUMASI}

The housing stock in Kumasi increased from 8, 475 houses in 1960 to 28, 622 houses in 1995 (Owusu, 2001). The housing stock in Kumasi reveals five distinctive house types: (Abloh, 1976, Tipple and Willis, 1991, Korboe, 1992, and Owusu, 2001); namely,

i) The single-storey traditional compound house: This is common in both the rural and urban areas. They are basically made up of an unroofed courtyard surrounded by a series of rooms with a simple pitched roof.

ii) The multi-storey compound house: This is similar to the single-storey compound house but may be 2 to 4 storeys high. Access is usually by a staircase in the courtyard on to a continuous balcony (Fig1b, Fig 1c).

iii) Government-built low-income housing: These are in the form of self-contained bungalows or rows of single rooms with shared facilities.

iv) Single family houses (bungalows):These are built on generously styled plots as large single family house. They are usually found on the periphery of the city centre.

v) Block of flats:These are mostly 2 to 4 self-contained units built 2 to 4 storeys high. They are usually not built on the courtyard concept and are for those who can afford high standards of housing and therefore high monthly rents. 
In terms of scope, this paper focuses on the multi-storey compound house.

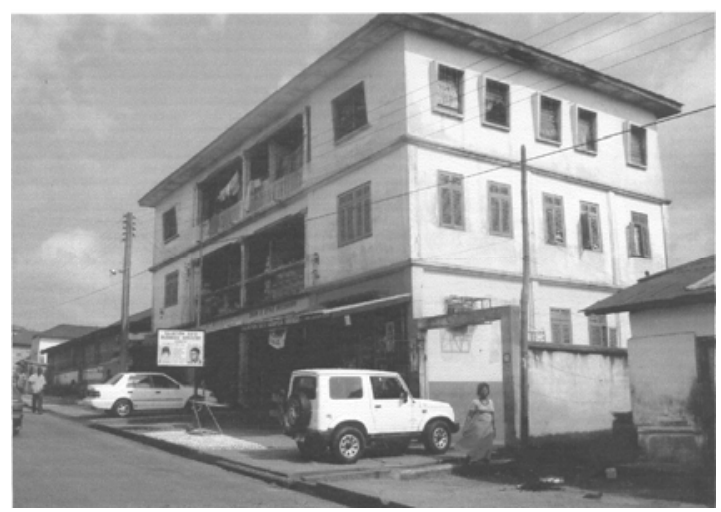

Fig. 1b: A Multi-storey compound house

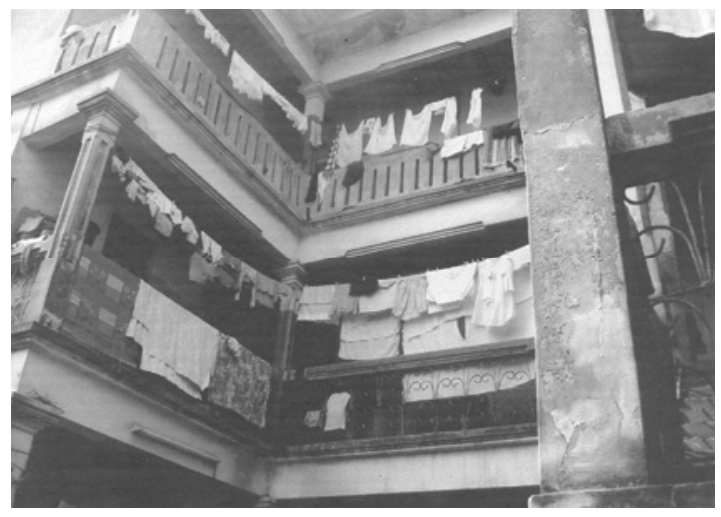

Fig. 1c: View from the compound (see mode of drying out laundry)

The "Single-storey traditional compound house' and the 'multi-storey compound house' sectors constitute what is referred to as the indegenious sector. The traditional house in Ghana is the compound house and these are usually built from traditional local materials and with local know-how that allow relatively low-income households to build for themselves.

The private sector controls approximately 84 percent of the houses in Kumasi. The mean housing density (ie. the number of houses per hectare) is 5.4 and the city-wide average number of persons per house is 26 . The housing areas of Kumasi are characterised by over-crowding, lack of maintenance, and over-stretched infrastructure and services (Owusu, 2001).

\section{TYPICAL COMPOUND HOUSE}

Winwoode Reade observed about the Ashanti compound house in 1874 that it is an ordinary house with one courtyard; a large house had three and the King's palace had ten or twelve courtyards" (Oliver, 1971 ).This tends to confirm that the modern day compound house has ancient beginnings. The urban compound houses are in two forms; the single storey and the multi-storey. The former are mostly built in earth-based materials and more common, while the latter in reinforced concrete and block work. Due to the present high cost of materials used in the latter, most of the urban poor households can only afford to build the single storey compound house.

From their rural origins as homesteads built around patches of bare ground, compound houses in Ghana have been adapted to suit urban conditions and demand for accommodation (Fig. 2). In the rural settings where land values are not high, people can afford to spread out (i.e. build horizontally) to create large compounds within these houses. This is diametrically opposed to what exist in the urban environment, where compatibility, high land values and the efficient use of land are some of the numerous factors that are considered in the provision of viable housing. One of the significant advantages of the single storey compound house is 
its ability to 'grow' by accretion ( Fig. 3a).

Fig. 2: Typical Ashanti Compound

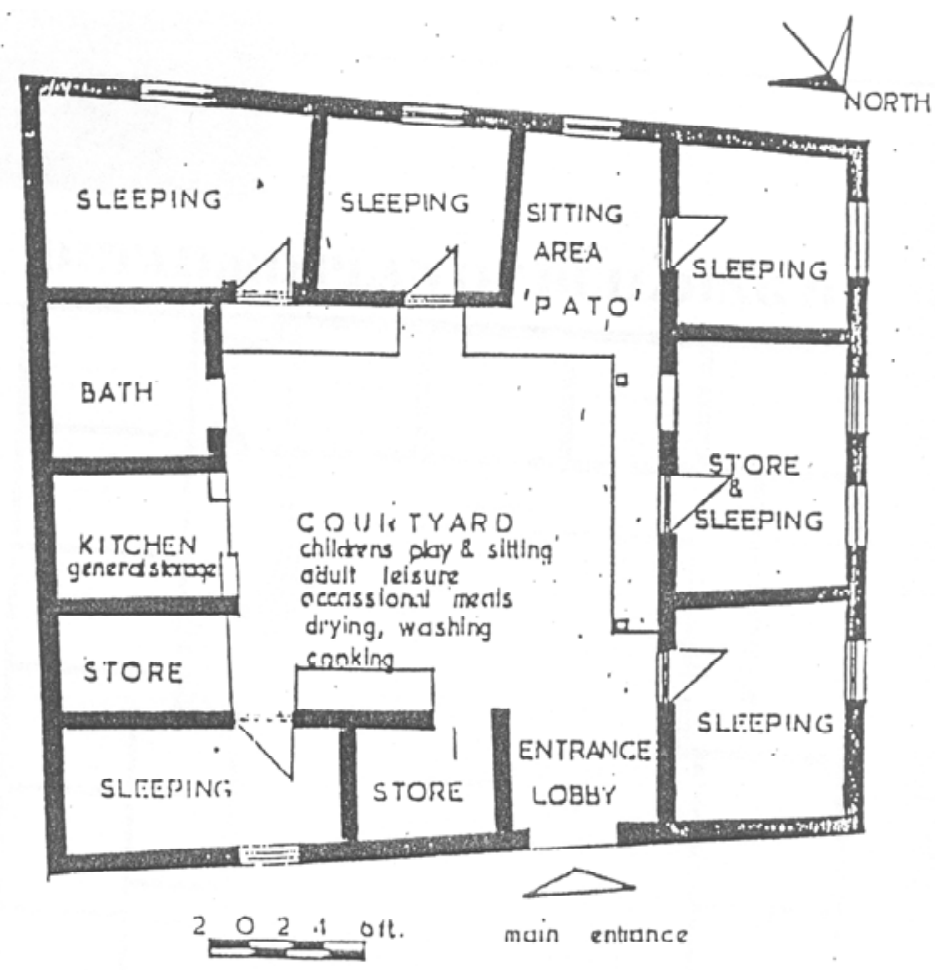

Source: Traditional dwelling formation as a concept for house design

(Building and Road Research Institute - UST, Kumasi, Ghana Current Report No. 12)

Fig. 3a: Compound House: Incremental Construction

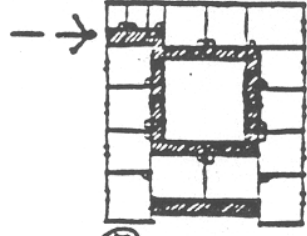

(3)

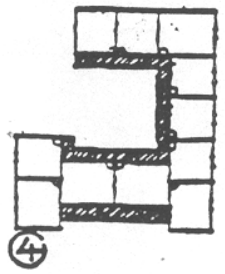

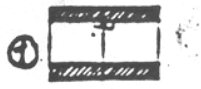

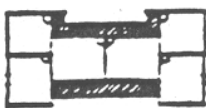

(2)

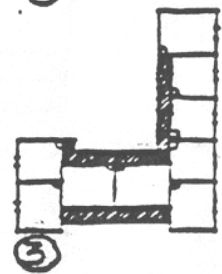

From the surveys conducted by the Department of Architecture, KNUST, the occupants of these compound houses are mostly people in the lower income bracket who live as households of about 4-6 persons (Department of Architecture, 2004 and 2005). This reflects the range of household sizes in the country as depicted in the Ghana Living Standards Survey of 2000.

Despite these households sizes most of them rent single rooms only. In Accra for instance, $66.5 \%$ of the 
households dwell in only one rented room whiles in other urban areas of the country they constitute $62.0 \%$. This rather disturbing phenomena is mainly due to their levels of income. (Korboe, 1992b). The mean annual income in the Ashanti Region was about 2,550,000 cedis in the year 2000 (about US\$277), (Statistical Service, 2000, Korboe, 1992b).

Many of the single-storey compound houses are built of traditional materials of rammed earth locally known as atakpame with wooden louvered windows; a few of them are built in sancrete blocks. The cost of a courtyard house of about twelve to fifteen rooms with shared kitchen and sanitary facilities built presently in sancrete is between 80 to 120 million cedis (US\$8,700 - US\$13,000) with monthly rents ranging between 20,000 to 60,000 cedis (US\$2.18 - US\$6.53) a month for a room as shown in Table 1. (Department of Architecture, 2005)

Table 1: The number of rooms per house and the levels of monthly rents in Bantama

\begin{tabular}{lccl}
\hline $\begin{array}{l}\text { House } \\
\text { Number }\end{array}$ & $\begin{array}{l}\text { Number of } \\
\text { rooms }\end{array}$ & $\begin{array}{l}\text { Number of } \\
\text { rented rooms }\end{array}$ & $\begin{array}{l}\text { Rent Levels } \\
\text { (cedis) }\end{array}$ \\
\hline Blk 112 & 8 & 4 & $20,000-40,000$ \\
Blk 113 & 5 & 0 & - \\
Blk 114 & 21 & 17 & $20,000-40,000$ \\
Blk 115 & 13 & 13 & $20,000-40,000$ \\
Blk 116 & 14 & 11 & 30,000 \\
Blk 117 & 23 & 15 & 40,000 \\
Blk 118 & 14 & 7 & $40,000-60,000$ \\
Blk 119 & 8 & 0 & - \\
Total & 98 & 70 & - \\
\hline
\end{tabular}

\section{Source: Department of Architecture, 2005 (Bantama Survey Report)}

Despite its prevalent use, the compound house in Ghana has a few shortcomings, which need to be examined in greater detail and solutions found. These short comings are even more acute if it is a multi-storey compound house where activities which are usually carried out on the ground floor within the courtyards have to be performed on upper floors. This tends to restrict the traditional way of life of the inhabitants living in these buildings. The beneficial aspects of the compound house, however, out-weigh its shortcomings.

The merits and demerits of compound houses are discussed in the following sections

\section{The merits:}

It is easy to build compound houses by accretion and they could even be occupied when only a couple of rooms have been built. This enables people to build according to the availability of funds. The need then for large capital outlays for the villas which cannot be occupied until they are completed, is then eliminated. (Fig3a)

The verandah in front of the rooms serve a variety of useful purposes. These activities included cooking, dining, storage and even as sleeping space, especially on warm, humid and breezeless nights. Also, outdoor activities performed by households are possible within the semi-public courtyard space without actually going out of the house, thus, providing some privacy. (Fig 3b). 
Fig. 3b: Compound House: Space Hierarchy
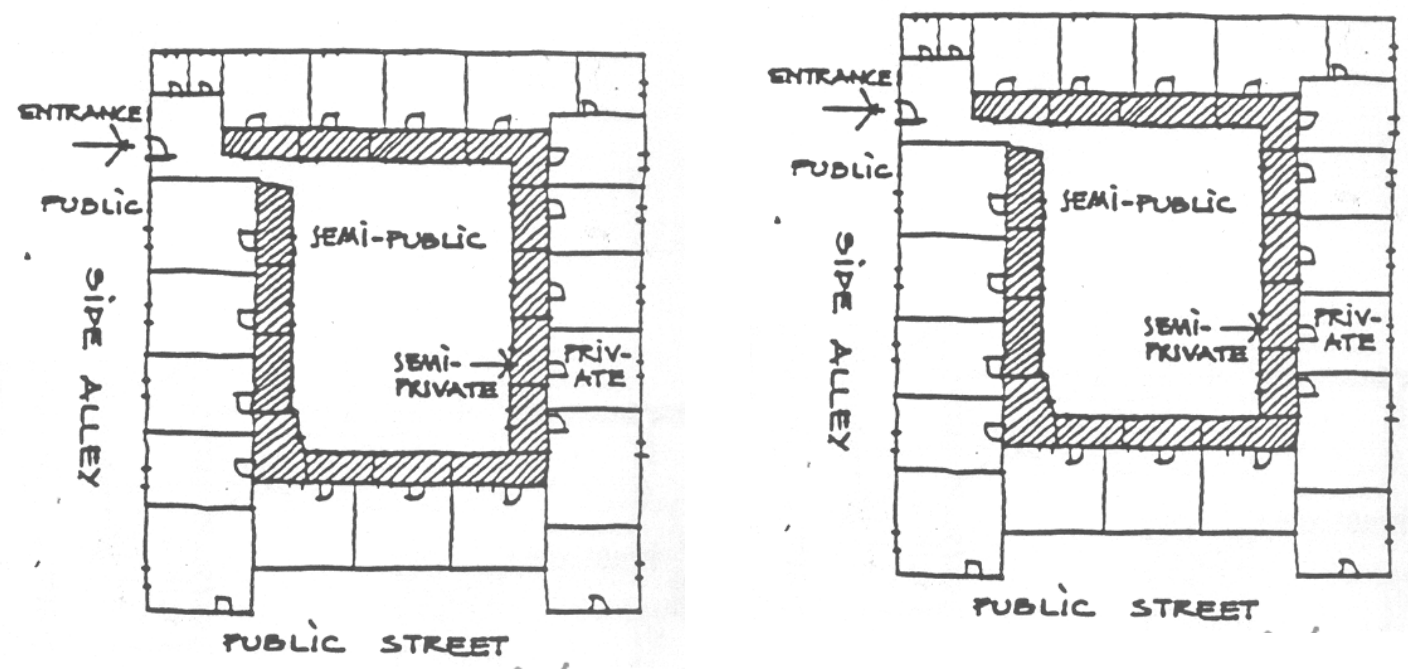

FUBLIC STREET.

An important merit often not recognised is that the nature of the compound, which allows multi-habitation, provides a twenty-four hour passive security. More importantly, the simple construction methods and building materials used for the single storey compound house make it cheaper and easier to build without resorting to highly skilled labour and sophisticated technology and equipment.

Adaptability is easily achieved with a compound house. Changing a room into a shop could be done merely by removing and replacing a window facing the main street with a door. This can be done without the slightest inconvenience to inhabitants of the adjacent rooms (Fig 4a). Furthermore, ventilation and lighting in compound houses are enhanced and are usually considered an ideal form of design for hot, humid areas such as Kumasi.

Fig. 4a: Figure showing the conversion of bedrooms along the street into shops in a Multi-storey Compound House

\section{DETAILED PLAN OF BUILDING B}

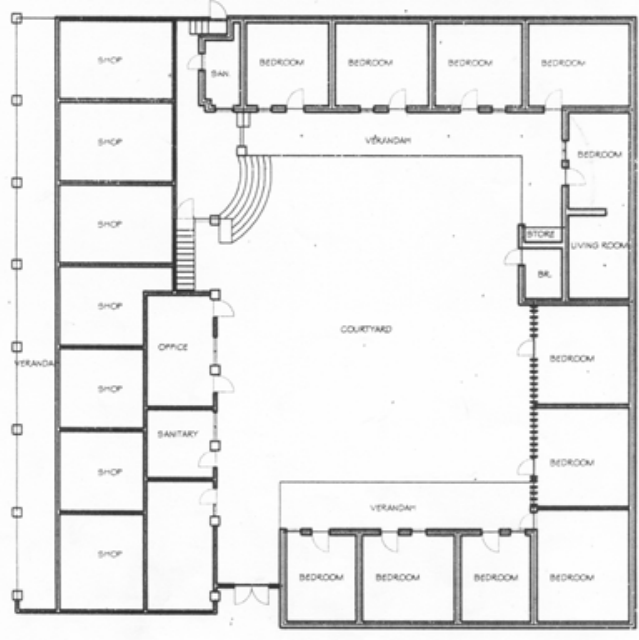

GROUND FLOOR PLAN

Source: Dept. of Architecture: (Bompata Survey Report 2005)

\section{The problems:}

Toilets are most times not centralised with regards to rooms within the courtyards of the compound houses. In recent times, the otherwise through-verandah is usually divided into defensible parts and separated from the 
central courtyard by short walls built by the tenants themselves, thereby disrupting effective circulation. This is an evidence of the need of private spaces for households.

The sharing of common meters for electricity and water by the various households most times create a great deal of disaffection among them due to the payment of high tariffs which are linked to consumption levels. This problem is further exacerbated by the kind and number of electric appliances a household may possess. There is even a humourous story about an illiterate landlord requesting a tenant to pay more for the use of electricity since his consumption level was higher. The reasons being that he always listens to foreign programmes instead of the local ones on his radio.

Drying of clothes within the undefined areas in the courtyard hinders free movement of people and flow of air. Another nuisance tenants often complain about is that in a multi-storey compound house they have to come down to the ground floor to pound 'fufu', a favourite Ghanaian dish and the staple food of the Ashantis. This is prepared with a wooden mortar and pestle. It is considered unsafe and acoustically inconvenient to do this on upper floors. However, people still do it due to the inconvenience of coming down to the ground floor. This practice causes vibrations and ultimate weakness in the structure of the building.

In most cases, there is also not enough space to dry clothes on the upper floors of the multi-storey compound house. The residents on such floors have to come down to the ground floor to do so.They string ropes between columns along the verandah and hang their clothes (Fig.1c). This reduces wind speeds needed for effective ventilation in rooms.

\section{Design innovations: The Future of the Compound House}

In the light of the problems that residents of multi-storey compound houses experience, four aspects of the lifestyle of the low-income househols would be considered in the proposed design innovations for the multi-storey compound house. These areas are fufu pounding, washing and drying of clothes, refuse disposal and utility space for relaxing and storage. However, the ability of the compound house to grow by accretion cannot be overlooked, since this could be used to create variable compounds and building sizes that could go to enhance these four aspects of the use of the property.

The improvements in the compound house design are discussed in the following sections.

Variable courtyard and building size

One aspect of the compound house that needs to be further enhanced is its ability to grow by accretion. This could be done by developing a module in order to help vary the size of the building and its compound (Korboe 1992) (Fig 4b). Module here denotes a defined structural or architectural space that could be taken out or added in the design and construction of the building as and when needed to either increase or decrease the floor area without it having any detrimental effect on the functions and use of that structure.

Fig. 4b: Module Concept of Design for the Design of Compound Houses

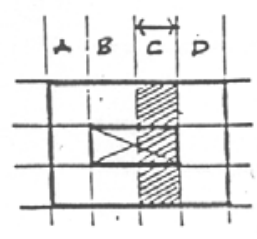

Module $C$ can be removed to reduce the size of building

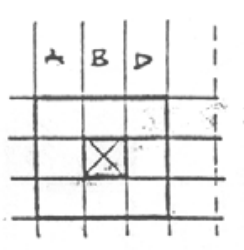

Module $C$ is replaced by Module C

Source: Korboe, 1992. The Low-income housing system in Kumasi:An empirical examination of two neighbourhoods

In the design shown in Fig $4 \mathrm{~b}$, various building sizes could be obtained by removing or adding a module. For instance, Module $\mathrm{C}$ has been removed and replaced with Module D. Other modules, E, F etc. could also be added, depending on the requirements of the development.

This means that a developer or household could develop modules A and B and still be able to house people 
even if the building is not complete. This would in no way be at cross-purposes with the building regulations in Ghana if the structure conforms to all regulations relating to building materials, ventilation, lighting, sanitary and health requirements, etc since this would be an example of the "growing house" concept already practiced in the country. The other modules could be added without any hindrance or inconvenience to the tenants. This therefore means that, with the construction of a multi-storey compound house, accretion could be in both directions - vertically and horizontally.

\section{Fig. 5a: Suggested Ground Floor Plan}

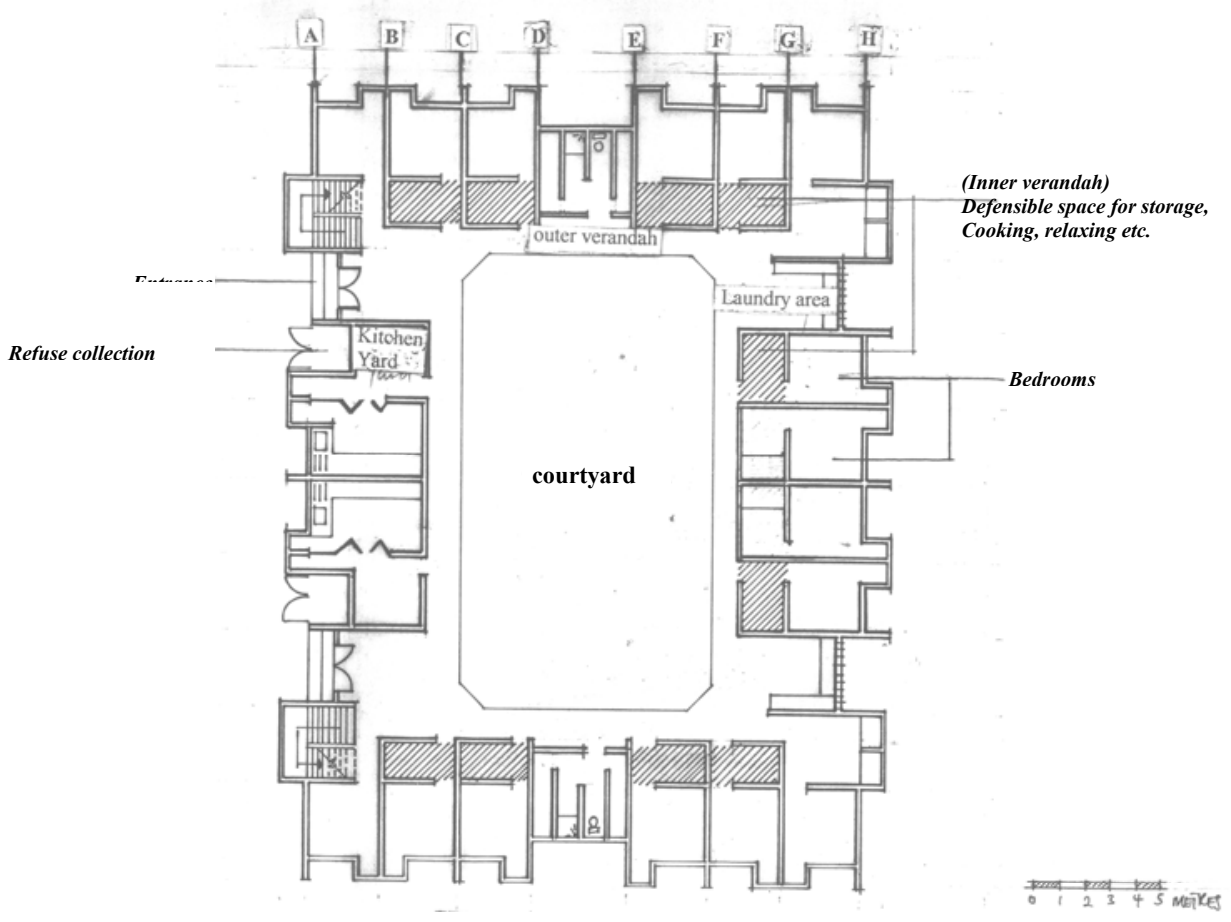

This principle has been translated into the plan in Fig. 5a and 5b. It would be realised that the module between grind $\mathrm{CD}$ and EF could easily be removed to reduce the size or added to increase it. The plan shows the possibility of providing accommodation for four families on each floor for a multi-storey compound house.

\section{Refuse disposal facility}

In almost all multi-storey compound houses no effort has been made to provide service stairs. A single stair leads to all the floors above, as such refuse generated is carried down the same stair which is normally used by the inhabitants upstairs. This is considered unhygienic and inconvenient. There is therefore the need to introduce a separate channel for the collection and disposal of refuse.

This can be achieved as shown in the plan in Fig.5b which shows a refuse disposal chute system that has a room on the ground (Fig. 5a) with a refuse container to facilitate the disposal of refuse from the various floors. A door opened from the outside on the ground floor enables collection to be done without anyone entering the compound.

\section{Utility space}

As stated earlier, the verandahs of most of the compound houses have been divided into 'defensible' spaces which tenants use as storage or cooking spaces for the exclusive use of their households. Others put chairs there to relax or even sleep during breezeless nights. The verandah has, therefore become a utility space. This shows the need for such space since most times tenants rent only a room or two which become so full of furniture and personal belongings such that the only place to sit under shade and enjoy some breeze without going out of the building is on the verandah. It also becomes an important place where neighbours 
exchange news and converse with the other tenants.

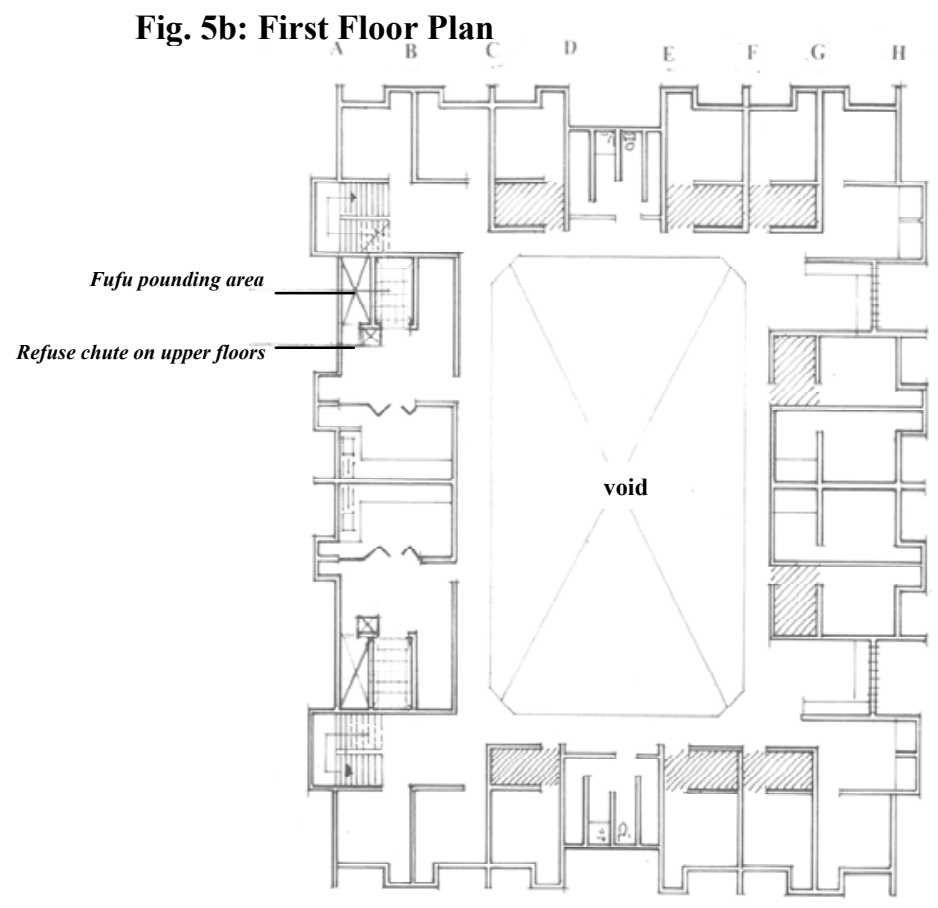

This tends to strengthen communal sentiments, thereby creating good neighbourliness. However, it prevents through circulation along the verandah. A change in the design of the compound house could easily resolve this situation. Examples of approaches at solving the problem are suggested in Figs.5a and $5 \mathrm{~b}$. Here outer and inner verandahs have been introduced. The inner one, which is shaded, would be used as a utility space for individual rooms and the outer one as a permanent circulation space. In such a situation, tenants could use the sanitary areas by walking under cover even if it rains without any impediments.

\section{Preparation of meals: Fufu pounding facility}

The method of preparation of fufu involves pounding the ingredients in a mortar with a pestle. This is considered structurally unsafe and acoustically inconvenient. Tenants presently living in the multi-storey buildings, persist in pounding on the upper floors. A few, however, come down from floors above to the ground floor to do that

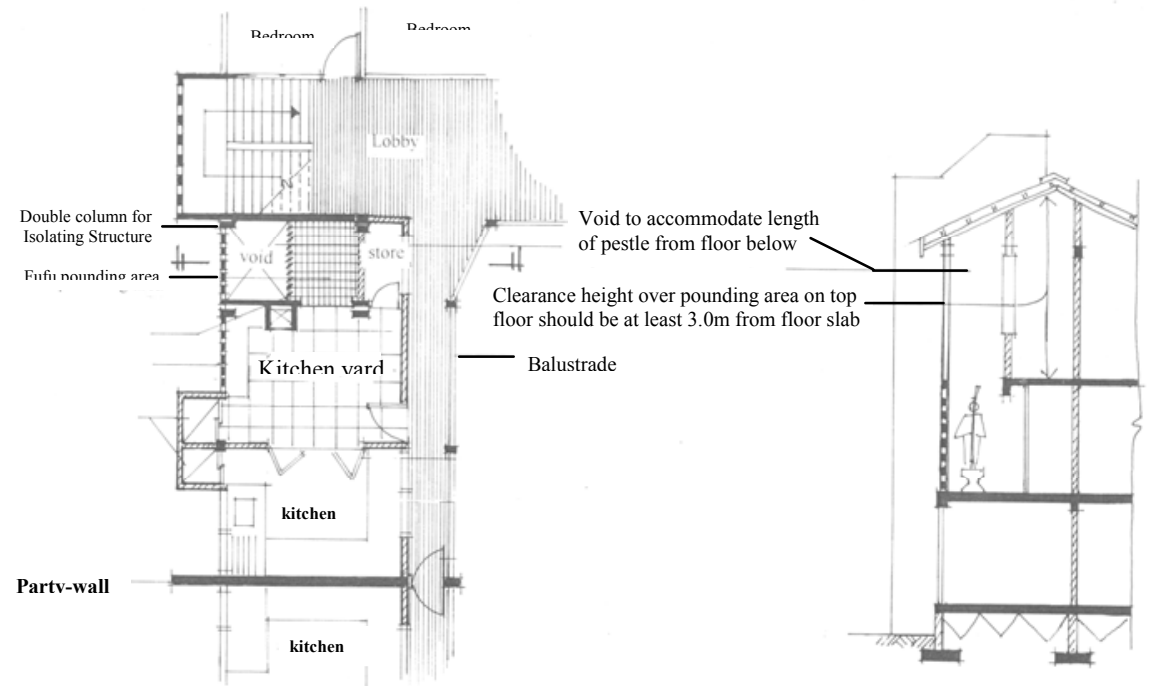

Fig. 6a: Detail of Kitchen/Fufu preparation area on upper floors
Fig. 6b: Section through fufu pounding area 
By way of introducing innovation in the design of these types of buildings, a part of the structure could be set aside and structurally isolated by using the "double column" concept (Figs $5 \mathrm{~b}$ and 6a). Here the area for pounding is structurally isolated from the main structure and insulation capable of absorbing sound is inserted between the two separate structures to help curtail sound transmission through them. The slab on the isolated area is further reinforced to be able to withstand the constant pounding. An indentation could also be made in the slab to accommodate the base of the mortar. A resilient material could be placed in it to help absorb the impact of pounding (Fig. 6c).

Fig. 6c: Section through an upper floor slab showing the double column concept with insulation between the isolated structure and the main structure

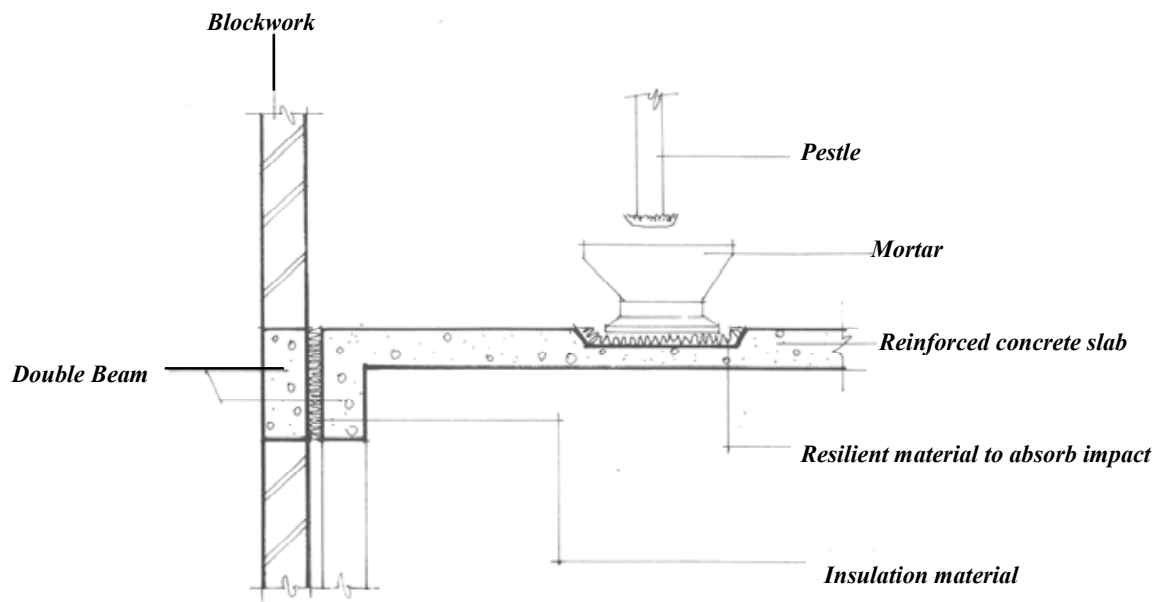

To complement this innovation, voids have been incorporated in the upper floors directly above these areas to accommodate the height of the pestle as it goes up in the pounding process (Fig. 6b). Pounding on the ground floors would be done in the open courtyard, as such none of the modifications in design have been proposed for the households on the ground floor.

\section{Washing and drying facilities}

Washing and drying of clothes on the ground floor is usually not a problem due to the courtyard space. However, these activities become a problem on the upper floors. Most tenants are compelled to come down to the ground floor to do their laundry since there are no designated areas for such an activity.

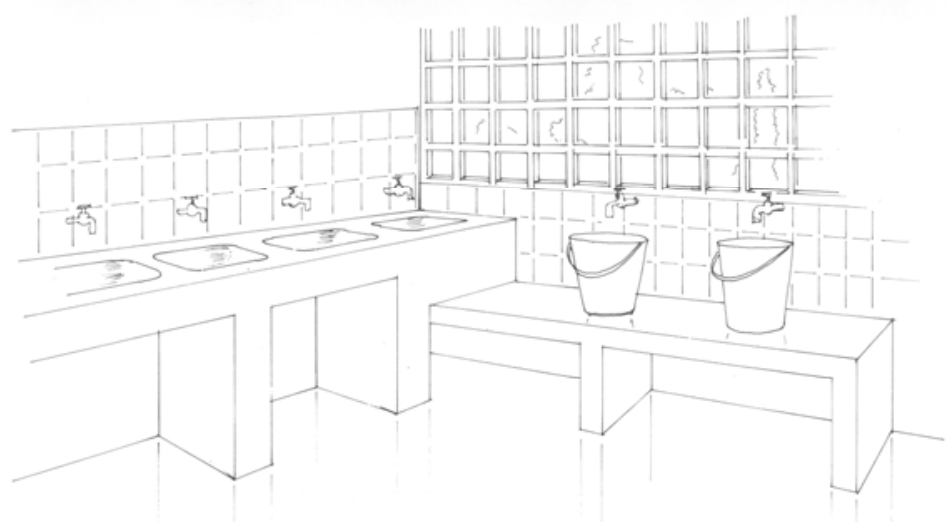

Fig. 7: Perspective of Laundry Area 
In the recommended changes, a specific area for washing has been designated on all the upper floors. In this case, washing sinks are to be provided with taps to enable washing to be done without the use of buckets. The other alternative or option is to provide a reinforced concrete slab, about $450 \mathrm{~mm}$ from the floor, to enable people to put buckets on or sit and wash with the buckets on the floor (Fig. 7).

However, drying of laundry has to be treated in a more sensitive manner due to the lack of space and other problems associated with ventilation. Usually, tenants hang their laundry on drying lines strung between columns on the verandah as well as on the balustrades (Fig. 1b). The ones on the upper floors are sometimes blown off onto the ground below since these cannot be held with pegs. Clothes which fall into the courtyard below are, however, not stolen due to the passive security provided by the courtyard-type of design. They may, however, be dirtied by children touching them or by dirt on the floor itself.

Laundry hung on drying lines between columns affect effective ventilation by reducing wind speeds. In the proposed changes in design to allow drying of laundry, tapering poles are inserted into galvanised tubes embedded in concrete balustrades at specific intervals along the length to the verandah (Figs. 8a, 8b). This would enable tenants more space to hang more clothes since this method would use up less space and also allow ventilation into rooms.

Fig. 8a: Shows method of drying of clothes on upper floors of a multi-storey compound house using tapering poles.

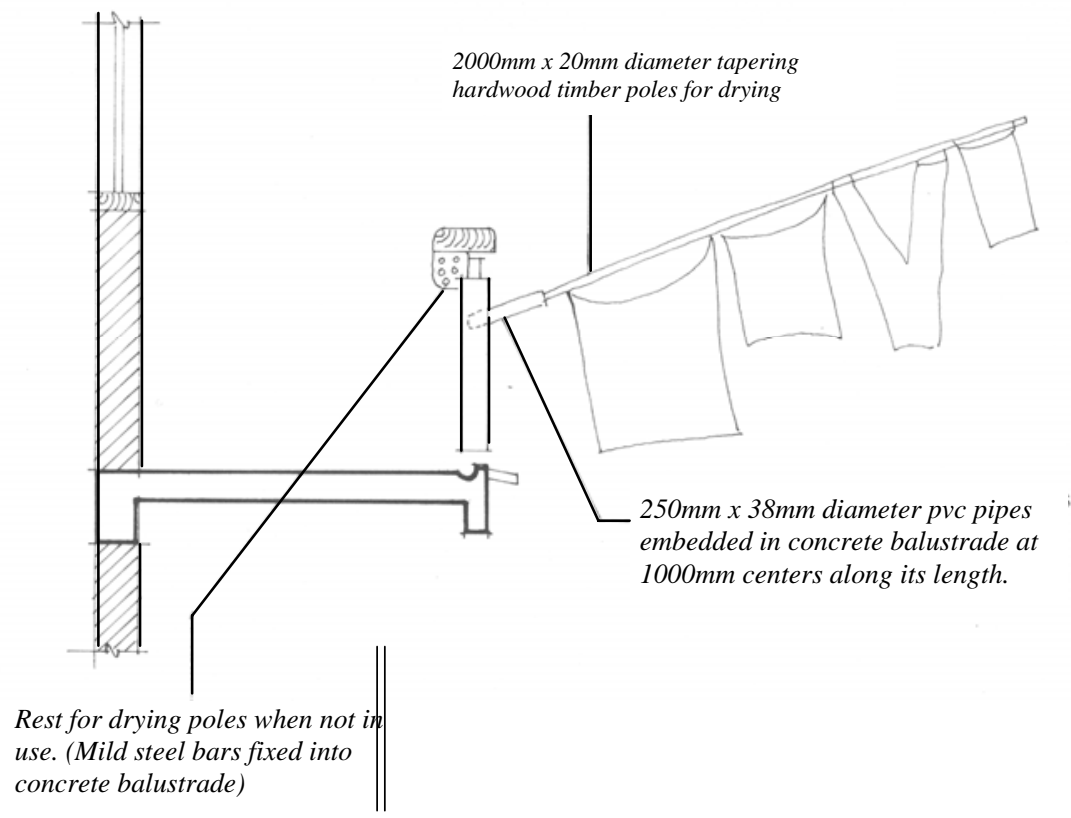

Fig. 8b: Perspective showing the method of drying clothes on upper floors of a multi-storey compound house

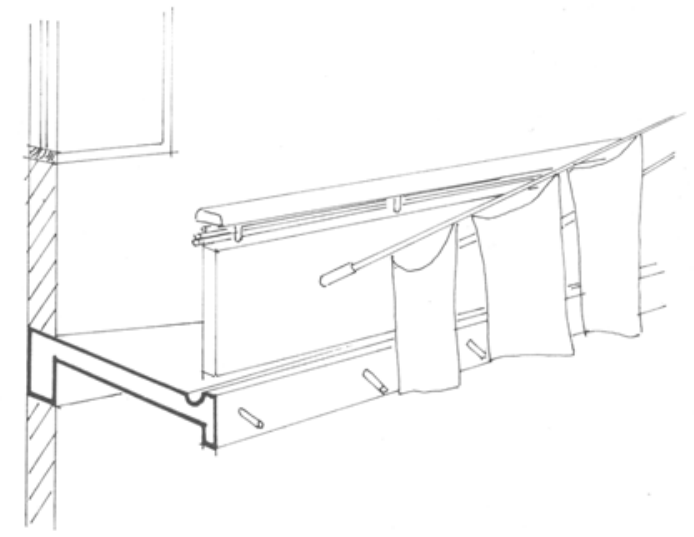




\section{CONCLUSION}

Even though there may be some advantages with building single storey compound houses, the multi-storey house addresses the realities of urban living due to rising costs and high land values. The paper has attempted, therefore, to address some of the difficulties experienced by tenants of this house type by, as it were, "rolling with the punch". The dynamic nature of cultures and the ever increasing power of the economic milieu, has transformed the village open courtyard concept of single storey dwellings into closed courtyard multi-storey houses. There is, therefore, the need for designs that would be sensitive to the needs of those who dwell in them.

Through the method of observation of the tenants' way of life, culture and tradition and studies carried out in some of the suburbs of Kumasi between 1986 - and 2005, alternative and more innovative designs of the multi-storey compound house have been recommended towards accommodating the growing number of urban low-income households under more "user friendly" conditions.

\section{REFERENCES}

Abloh, F.A. (1976). Housing Areas in a Ghanaian Urban Centre, Department of Housing and Planning Research, KNUST, Kumasi.

Department of Architecture, (2004). Adum Urban Study: Survey Report, Department of Architecture, College of Architecture, KNUST (unpublished).

Department of Architecture, (2005). Bantama Study: Survey Report, Department of Architecture, College of Architecture, KNUST (unpublished).

Department of Architecture, (2005). Bompata Study: Survey Report, Department of Architecture, College of Architecture, KNUST (unpublished).

Korboe, D. (1992b). "Multi-habitation- An Analysis of Low-Income Residence in a West African City: Open House International 17/1:45-53.

Korboe, D. (1992). The Low-Income Housing System in Kumasi: An empirical examination of two neighborhoods: (Unpublished PhD Dissertation, University of Newcastle Upon Tyne).

Oliver, P. (ed) (1971). Shelter in Africa: London: Barrie and Jenkins.

Owusu, S.E. (2001). Housing Supply and Demand in Kumasi, Ghana, in K.K. Adarkwa and Johan Post (ed); The Fate of the Tree: Planning and Managing the Development of Kumasi, Ghana: Woeli Publishing Services, Accra.

Statistical Service (2002). Population and Housing Census, Summary Report of Final Result, March 2002. Accra

Statistical Service, (2000). Ghana Living Standard Survey: Accra Statistical Service. Accra

Tipple, A. G. (1987). The Development of Housing Policy in Kumasi, Ghana, 1901-1981, Newcastle, University of Newcastle upon Tyne.

Tipple, G. and Willis, K. (1991). Tenure Choice in a West African City: Third World Planning Review. 13/1:27-45. 